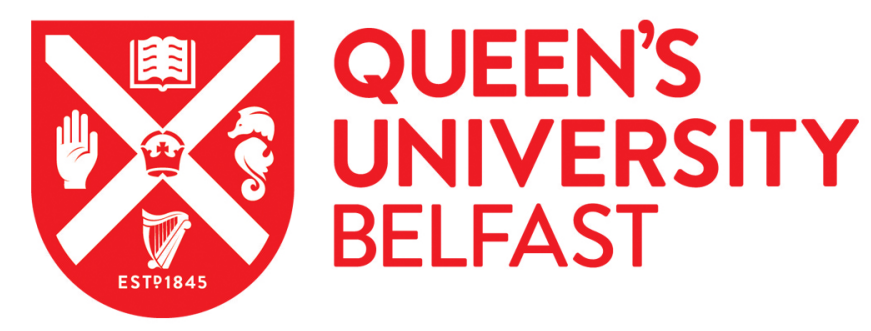

\title{
Prevalence of Psychotic-Like Experiences and Associated Distress in Adolescent Community, Sexual-Trauma and Clinical Samples
}

Nolan, E., Murphy, S., O'Neill, T., Houston, J., Murphy, J., \& Shevlin, M. (2018). Prevalence of Psychotic-Like Experiences and Associated Distress in Adolescent Community, Sexual-Trauma and Clinical Samples.

Psychosis: Psychological, Social and Integrative Approaches. https://doi.org/10.1080/17522439.2018.1511745

Published in:

Psychosis: Psychological, Social and Integrative Approaches

Document Version:

Peer reviewed version

Queen's University Belfast - Research Portal:

Link to publication record in Queen's University Belfast Research Portal

Publisher rights

Copyright 2018 Taylor and Francis. This work is made available online in accordance with the publisher's policies. Please refer to any applicable terms of use of the publisher

\section{General rights}

Copyright for the publications made accessible via the Queen's University Belfast Research Portal is retained by the author(s) and / or other copyright owners and it is a condition of accessing these publications that users recognise and abide by the legal requirements associated with these rights.

Take down policy

The Research Portal is Queen's institutional repository that provides access to Queen's research output. Every effort has been made to ensure that content in the Research Portal does not infringe any person's rights, or applicable UK laws. If you discover content in the Research Portal that you believe breaches copyright or violates any law, please contact openaccess@qub.ac.uk. 
Prevalence of Psychotic-Like Experiences and Associated Distress in Adolescent Community, Sexual-Trauma and Clinical Samples.

Emma Nolan ${ }^{1}$, Siobhan Murphy ${ }^{2}$, Tara O’Neill ${ }^{3}$, James Houston ${ }^{1}$, Jamie Murphy ${ }^{1}$ and Mark Shevlin ${ }^{1}$.

School of Psychology, Ulster University ${ }^{1}$

National Centre for Psychotraumatology, Southern Danish University ${ }^{2}$ School of Psychology, Queen's University Belfast ${ }^{3}$

Corresponding Author: Professor Mark Shevlin, School of Psychology and Psychology Research Institute, Ulster University, Magee campus, Londonderry, BT48 7JL, Northern Ireland, Tel: +44 (0)28 71375619, Email: m.shevlin@ulster.ac.uk 


\section{Abstract}

The current study sought to assess and compare the frequency of psychotic-like experiences (PLEs) and the associated levels of distress across three groups (adolescent community, sexual-trauma survivors, and a clinical group of participants with serious mental health problems). Participants completed a revised version of the Adolescent Psychotic-like Symptom Screener (APSS) that was adapted to include ratings of the degree of distress associated with each PLE. Results showed that the adolescent community sample was less likely to report PLEs and found them less distressing compared to the sexual-trauma survivors and clinical sample. Sexualtrauma survivors reported more PLEs and found them more distressing than the adolescent community sample. The clinical sample consistently reported more PLEs than both the adolescent community and sexual-trauma sample, and was more likely to report PLEs as very distressing compared to any other distress subscale. The most distressing PLEs for the adolescent community sample was paranoia, for the sexualtrauma and clinical sample they were paranoia and auditory hallucinations. These results draw support for the cognitive approach to psychosis, add further support to the hypothesis of a psychosis continuum, and perhaps indirectly, provide evidence for a continuum of distress that maps onto an inferred continuum of risk.

Keywords; Psychotic-Like Experiences, Distress, Risk, Community, Sexual-Trauma, Clinical. 


\section{Prevalence of Psychotic-Like Experiences and Associated Endorsements of \\ Distress in Adolescent Community, Sexual-Trauma and Clinical Samples.}

\section{Introduction}

There has been a plethora of research investigating psychotic-like experiences (PLEs) in the general population. It is now widely accepted that PLEs, although transitory and usually not requiring psychiatric intervention, are common in healthy populations. Consequently, the psychosis phenotype is now considered a continuum (Kendler et al., 1996; Van Os et al., 2001; Dhossche et al., 2002; Johns et al., 2004). Evidence for the psychosis continuum has been demonstrated by factor analytic studies that have shown replicable, multidimensional structures in both clinical and non-clinical samples (e.g. Shevlin et al., 2015; Reininghaus et al., 2012). These studies have demonstrated alternative models of factor structures ranging from two, three, four and five factors, which include, positive symptoms (hallucinations and delusions), negative symptoms, cognitive disorganization, depression and mania (see; Mellers, Sham, Jones, Toone, \& Murray,1996; Murphy, Shevlin, Adamson, \& Houston,2010;Barragan Laurens, Navarro, \& Obiols,2011; Stefanovics, Elkis, Zhening, Zhang, \& Rosenheck,2014;Wigmanetal.,2012;Yungetal.,2009).

There have been several studies demonstrating that PLEs do not delineate a general population and a population with clinically meaningful psychotic symptoms, rather they demonstrate a continuous gradation of risk (Kaymaz et al., 2012) and are present in healthy individuals, high-risk groups and clinical samples. These studies and their findings are summarised in Table 1.

[Table 1 here]. 
In summary, these studies show that PLEs are present in healthy, high risk and clinical groups and share similar etiological risk factors with psychotic disorders. As it is evident that PLEs cluster together in similar ways at clinical, subclinical and general population levels (Shevlin, McElroy, Bentall, Reininghaus, \& Murphy, 2016), it has been argued that clinical relevance is distinguished if these experiences engender distress, prompt help seeking behaviour, and/or impair functionality.

In this study, we sought to estimate the frequency of endorsement and associated distress of PLEs in adolescent community, sexual-trauma exposed, and clinical samples. The adolescent community and clinical samples were used as they clearly represent the lower and upper end of the hypothesised psychosis continuum. The sexual-trauma survivors were selected to represent a high-risk trauma exposed group; there has been extensive research that suggests trauma, particularly of a sexual nature, is a significant risk factor for clinically relevant psychosis (Varese et al.,2012). The three groups in this study represent proxies for different dimensional positions along the continuum. Although it was expected that the clinical group would report symptoms most frequently and find PLEs more distressing, inclusion of this group was crucial to represent a clinical group for comparison. It was predicted that PLE's would be reported less frequently in the non-clinical samples compared to the clinical sample, and the sexual-trauma sample would report more PLEs than the adolescent community sample. Second, we aimed to present the associated levels of distress of endorsed PLEs. Similarly it was predicted that PLEs would be less distressing in the non-clinical samples compared to the clinical sample, and the sexual-trauma sample would report PLEs as being more distressing than the adolescent community sample. Finally, in estimating the overall endorsement and distress of PLEs in these three 
groups, we aimed to compare the strength of PLE endorsements and the degree of distress scores of each PLE within each group

\section{Method}

\section{Samples.}

Data from 1,112 participants were used from three independent samples; (1) adolescent community $(\mathrm{N}=794),(2)$ female survivors of sexual-trauma $(\mathrm{N}=268)$ and (3) participants with serious mental health problems using supported living services $(\mathrm{N}=50)$. Across all three samples the mean age was 21.4 years $(\mathrm{SD}=10.43)$ with $65.6 \%$ of the total sample being female.

Sample 1 consisted of 794 post-primary school adolescents. The mean age of the participants was 16.20 years $(\mathrm{SD}=1.06)$ with $440(55.4 \%)$ being female. Participants were recruited from ten post primary schools in Northern Ireland (response rate was 32.7\%). Ethical permission to conduct the study was obtained from the local ethics committee and parental 'opt-in' consent was required. After agreeing to participate, the principal of the schools met with the teachers responsible for years 12,13 and 14 and described the aims of the study, data collection process and confidentiality procedures. Details of recruitment and the sample are provided in Murphy, Murphy, and Shevlin (2015).

Sample 2 consisted of 268 female help-seeking sexual-trauma survivors. Participants were recruited, with the help of website administrators, via websites and forums, which specifically offered discussion forums, support and advice to sexual-trauma survivors. Participants were recruited from 11 different Internet forums with the majority of contributors coming from Pandys.org (36.5\%), Aftersilence.org (20.5\%) 
and Psychforums.com (15\%). Participants were invited to complete an online questionnaire. Potential participants were required to be active users and full members of the particular website/forum for inclusion in the study. Exclusion criteria applied to those who had not experienced sexual-trauma, and were visiting the sites for information purposes only, (i.e. partners, parents, friends or professionals). The mean age for the sample was 32.10 years $(\mathrm{SD}=10.61)$.

Sample 3 consisted of 50 participants who were recruited in partnership with a provider of supported living services. Service users from nine mental health supported living and domiciliary care services participated in this study. Most participants had a diagnosis of schizophrenia $(84 \% ; n=42), 12 \%(n=6)$ reported they had bipolar disorder, and 4\% $(n=2)$ did not disclose their diagnosis. The sample consisted of 28 males $(56 \%)$ with a mean age of 45.80 years $(\mathrm{SD}=12.3)$. The mean age of first admission to psychiatric services was 25.73 years $(\mathrm{SD}=8.4)$.

Ethical approval for all studies was granted by the Ulster University Institutional Review Board.

\section{Measures.}

The Adolescent Psychotic-like Symptom Screener (APSS: Kelleher, Harley, Murtagh, \& Cannon, 2011). This measure incorporates 7 items assessing hallucinatory and delusional experiences (items are presented in Table 2). Items were rated on a 4-point Likert scale and scored 1 (Never), 2 (Sometimes), (3) Often, (4) Nearly Always to give an overall frequency score of endorsement of psychotic-like experiences. If an individual answered, 'Sometimes', 'Often' or 'Nearly Always' to experiencing a PLE 
they were then asked 'How distressing did you find this?' There were 4 possible responses of degree of distress: ‘(1) Not distressed', '(2) A bit distressed', ‘(3) Quite distressed', and '(4) Very distressed'. If a participant answered "Never" to experiencing a PLE they were not prompted to answer the distress question and thus not included in the distress scores. Both frequency and distress rating were dichotomised with endorsement being represented as a score greater than 1 for both scales. Kelleher et al., (2011) reported good predictive validity and good specificity and sensitivity for the APSS in its ability to identify psychotic like experiences in the population.

\section{Results}

Counts and percentages were calculated for each of the APSS items for each of the groups and these are reported in Table 2. For each PLE a chi-square test was used to assess if there was a significant association between participant group (adolescent community, sexual trauma, clinical) and frequency of endorsement/distress ratings. Carmer's v was used to assess the strength of association $($ small $=.10$, medium $=.30$, large $=.50:$ Cohen, 1988)

[Table 2 here].

In general, participants from the clinical sample endorsed PLEs more frequently compared to the sexual-trauma sample and the adolescent community sample. The sexual-trauma sample endorsed more PLE items compared to the adolescent community sample. Generally, the adolescent community group were the least likely to endorse any form of PLE. Overall, the most frequently endorsed PLEs for the 
adolescent community sample was paranoia (40.5\%) and the belief that others could read their mind (38.5\%). For the sexual-trauma sample the most frequently reported PLEs were paranoia (59.7\%) and auditory hallucinations (AHs: 54.8\%). For the clinical group the most frequently endorsed PLEs were also paranoia $(62.0 \%)$ and AHs (78.0\%). The results from the chi-square tests confirmed that the endorsement rates differed across the three groups in the predicted way, with the largest effect sizes found for auditory (.23) and visual hallucinations (.19).

Counts and percentages of the distress associated with endorsed PLEs are reported in Table 3.

[Table 3 here].

In general, the clinical sample was more likely to report PLEs as being distressing compared to the sexual-trauma and adolescent community sample. The PLEs that caused the most distress for the clinical group was paranoia (100\%) and AHs (94.7\%). The sexual-trauma sample reported greater percentages of distress compared to the adolescent-community sample. The PLEs that caused the greatest distress for the sexual-trauma sample was paranoia (94.4\%) and AHs (80.9\%). The adolescent group reported lower levels of distress compared to the other groups. The PLEs most likely to cause distress for this group was also, paranoia (81\%) and AHs (67.3\%). In all three samples the most distressing (Very distressed) PLE was paranoia. The results from the chi-square tests confirmed that the distress ratings differed across the three groups in the predicted way. The largest effect sizes were for 'Thoughts read' (.38) and 'Messages sent through TV or radio' (.41), small to 
medium associations were found with 'Thought control' (.28), 'AH' (.28) and 'Paranoia' (.28).

The strength of PLE endorsements and the degrees of distress associated with each endorsed PLE follows the same pattern. The adolescent-community sample had greater percentages of PLEs occurring 'Never' compared to the other groups and reported greater percentages of PLEs as 'Not distressing'. The sexual-trauma sample had greater percentages of PLEs occurring 'Often' and 'Sometimes' and reported greater percentages of these PLEs being 'A bit distressing' and 'Quite distressing'. The clinical sample had greater percentages of PLEs occurring 'Nearly always' and reported greater percentages of these PLEs being 'Very distressing'. Overall, these results show that the strength of endorsements and degrees of distress associated with PLEs increase in the predicted direction across the three groups.

\section{Discussion}

This study aimed to estimate the frequency of endorsement of PLEs and associated distress, in three different sample groups. It was predicted that PLEs would be reported less frequently in the adolescent community sample compared to the sexualtrauma sample, and the sexual-trauma sample would report less PLEs than the clinical sample. This hypothesis was supported. In general, the adolescent community had lower percentages of endorsed PLEs, and the clinical sample had greater percentages of endorsed PLEs. For the adolescent community and sexual-trauma samples, the most common PLE was paranoia, and for the clinical sample it was AHs. Other studies that have reported specific PLEs have found similar results, finding that the 
most common experiences are $\mathrm{AH}, \mathrm{VH}$, and paranoia (e.g. Horwood et al.,2008; McGrath et al.,2015; Kinoshita et al.,2011;Shevlin,Murphy, Dorahy, \& Adamson,2007;Smeetsetal.,2010; for other studies see Table 1). Thus it is argued that when understanding PLEs across the psychosis continuum they do not differ in type, rather, the difference occurs in the percentages of endorsement and related distress (Remberk,2017).Second, we aimed to assess the overall distress associated with the endorsed PLEs within the three groups. It was predicted that PLEs would be less distressing in the non-clinical samples compared to the clinical sample. The sexualtrauma sample would report PLEs as being more distressing than the adolescent community sample, and the clinical sample would find PLEs the most distressing. This hypothesis was supported. The adolescent community found PLEs the least distressing, generally reporting PLEs as not distressing. The sexual-trauma sample had greater reports of PLEs as being distressing compared to the adolescent community sample, and the clinical sample reported PLEs as more distressing compared to the other groups. Additionally, the strength of PLE endorsements and associated degrees of distress showed the same pattern within the three groups and differed in the predicted direction. The final aim of the study was to identify which PLEs were reported as being the most distressing in nature within each sample. For all groups paranoia and AHs were rated as the most distressing. These results are in line with arguments throughout the literature that suggest the interpretation of PLEs is what causes these experiences to be associated with distress (see;Morrison,2001). Brett, Heriot-Maitland, McGuire, and Peters (2014) found that a healthy population sample appraised PLEs as benign whereas two different clinical groups of individuals appraised these experiences more negatively. In cognitive approaches to psychosis, it is argued that distress should be the focus of treatment and not the symptom. Research 
is continually demonstrating a role for trauma exposure and PTSD in the development of hallucinations and paranoia, and supports theoretical models regarding the developmental impact of trauma on psychosis (Hardy et al., 2016). Evidence from epidemiological surveys, prospective studies and case-control studies, adds further support for a causal link, in that particular events may be more likely to trigger specific psychological mechanisms (Hardy et al., 2016), and that certain groups may be prone to specific types of PLEs. Shevlin et al. (2007) demonstrated associations between specific childhood traumas and different types of hallucinations. They found four types of childhood trauma (physical abuse, neglect, rape, and molestation) were all associated with an increased likelihood of experiencing hallucinations, while auditory hallucinations were associated with sexual childhood trauma only. Bentall et al. (2012) also found that respondents who reported being raped in childhood were nine times more likely to experience auditory verbal hallucinations. They also reported that children who had been in care were five times more likely to experience paranoia. The specific associations that have been found between childhood adversities and specific PLEs demonstrates the importance of understanding how particular experiences may be casual factors in the development of specific PLEs. Thus, differentiating PLEs, for example $\mathrm{AH}$ and $\mathrm{VH}$, as different experiences will develop a better understanding of the phenomenological characteristics that define these occurrences and how they may develop along the psychosis continuum. Within this study, paranoia and $\mathrm{AH}$ were the most frequently reported, and resulted in increased feelings of distress for non-clinical, sexual-trauma, and clinical samples. It demonstrates that, at the upper end of the continuum of psychosis, or perhaps, a continuum of risk, there is not only increased endorsement but also an increased perception of distress. Associations between specific traumas and symptoms of 
psychosis further support the cognitive-behavioural models of psychosis that highlight the role of cognitive-affective processes in symptom development and maintenance (Hardy et al., 2016). Freeman and Garety (2014) argue that interventions modifying trauma-related affect regulation and beliefs will have a benefit in targeting these underlying effects that increase the chance of psychotic experiences. This further supports the argument that an increased understanding of specific PLEs will lead to a more sophisticated categorization of the phenomenon, which in turn will improve the reliability of assessments, provide more focused interventions (Waters et al., 2012), and shed light on the mechanisms in which risk translates into disorder. This study does have its limitations. While it's the first study to examine the frequency and distress associated with specific PLEs, the assessments were all self-report without clinical verification. Although the total sample size was large, the sample sizes differed greatly across the three samples meaning that the precision of measuring PLEs was probably poorer in the smaller groups. The groups also differed in terms of gender ratio; the results from the all-female sexual-trauma group may not be representative of other high-risk traumatised groups. Therefore, it is suggested this demographic variable should be controlled for in later studies. Furthermore, future studies should investigate and control for existing mental health problems. It is likely that the sexual-trauma sample had current mental health problems. Studies have found that problems such as depression and anxiety are amongst the strongest predictors of transition to psychosis in high-risk populations (Johnstone, Ebmeier, Miller, Owens, \& Lawrie,2005).It is of note that data on adolescents suggests that rates of PLEs are higher among this age group, which may account for the high prevalence rates in the general population sample. Barragan et al. (2011) found that $58.9 \%$ of the children reported "certain experience" of one or more PLEs. Additionally, Poulton et al. 
(2000) found that at age 11,86\% reported PLEs, and Yunget al. (2009) found that $99.1 \%$ of individuals responded positively to sometimes experiencing PLEs. It is possible that due to the age group of the adolescent community sample, mean age of 16, that prevalence rates were higher. However, it is not uncommon to have prevalence rates this high in general community samples. Armando et al. (2010) found that persecutory ideation PLEs had prevalence, with $92.3 \%$ endorsing at least 1 item "sometimes", followed by grandiose delusions, whereby $74.8 \%$ endorsed at least one item. These findings draw support for the fundamental cognitive approach to psychosis (Bentall et al.,2001; Garety, Kuipers, Fowler, Freeman, \& Bebbington,2001; Morrison,2001), which deems the appraisal, response, and social context, rather than necessarily the anomalous experience itself, as the potential detriments of transition. The results are thefirst to allow a comparison of the PLEs that may influence risk across samples by elucidating those PLEs that may be more distressing. Future research is needed to determine if other high-risk groups (e.g. those with a family history of mental illness, physical abuse, and near death experiences) create different patterns of endorsement and distress rates of PLEs.

\section{References}

Armando, M., Nelson, B., Yung, A. R., Ross, M., Birchwood, M., Girardi, P., \& Nastro, P. F. (2010). Psychotic-like experiences and correlation with distress and depressive symptoms in a community sample of adolescents and young adults. Schizophrenia Research, 119(1-3), 258-265. 
Barragan, M., Laurens, K. R., Navarro, J. B., \& Obiols, J. E. (2011). Psychotic-like experiences and depressive symptoms in a community sample of adolescents. European Psychiatry, 26(6), 396-401.

Bentall, R. P., Wickham, S., Shevlin, M., \& Varese, F. (2012). Do specific early-life adversities lead to specific symptoms of psychosis? A study from the 2007 the Adult Psychiatric Morbidity Survey. Schizophrenia Bulletin, 38(4), 734-740.

Brett, C., Heriot - Maitland, C., McGuire, P., \& Peters, E. (2014). Predictors of distress associated with psychotic - like anomalous experiences in clinical and non - clinical populations. British Journal of Clinical Psychology, 53(2), 213227.

Cohen, J. (1988). Statistical power analysis for the behavioral sciences (2nd ed.). Hillsdale, NJ: Lawrence Earlbaum Associates.

Cougnard, A., Marcelis, M., Myin-Germeys, I., De Graaf, R. O. N., Vollebergh, W., Krabbendam, L., ... \& Van Os, J. (2007). Does normal developmental expression of psychosis combine with environmental risk to cause persistence of psychosis? A psychosis proneness-persistence model. Psychological Medicine, 37(4), 513-527.

Dhossche, D., Ferdinand, R., van der Ende, J., Hofstra, M. B., \& Verhulst, F. (2002). Diagnostic outcome of self-reported hallucinations in a community sample of adolescents. Psychological Medicine, 32(4), 619-627.

Dominguez, M. D. G., Wichers, M., Lieb, R., Wittchen, H. U., \& van Os, J. (2009). Evidence that onset of clinical psychosis is an outcome of progressively more persistent subclinical psychotic experiences: an 8-year cohort study. Schizophrenia Bulletin, 37(1), 84-93. 
Freeman, D., \& Garety, P. (2014). Advances in understanding and treating persecutory delusions: a review. Social Psychiatry and Psychiatric Epidemiology, 49(8), 1179-1189.

Gale, C. K., Wells, J. E., McGee, M. A., \& Browne, O. (2011). A latent class analysis of psychosis-like experiences in the New Zealand Mental Health Survey. Acta Psychiatrica Scandinavica, 124(3), 205-213.

Garety, P. A., Kuipers, E., Fowler, D., Freeman, D., \& Bebbington, P. E. (2001). A cognitive model of the positive symptoms of psychosis. Psychological Medicine, 31(2), 189-195.

Hanssen, M., Bak, M., Bijl, R., Vollebergh, W., \& Van Os, J. (2005). The incidence and outcome of subclinical psychotic experiences in the general population. British Journal of Clinical Psychology, 44(2), 181-191.

Hardy, A., Emsley, R., Freeman, D., Bebbington, P., Garety, P. A., Kuipers, E. E., ... \& Fowler, D. (2016). Psychological mechanisms mediating effects between trauma and psychotic symptoms: the role of affect regulation, intrusive trauma memory, beliefs, and depression. Schizophrenia Bulletin, 42(1). 34-S43.

Horwood, J., Salvi, G., Thomas, K., Duffy, L., Gunnell, D., Hollis, C., \& Zammit, S. (2008). IQ and non-clinical psychotic symptoms in 12-year-olds: Results from the ALSPAC birth cohort. The British Journal of Psychiatry, 193(3), 185-191. Johns, L. C., Cannon, M., Singleton, N., Murray, R. M., Farrell, M., Brugha, T., \& Meltzer, H. (2004). Prevalence and correlates of self-reported psychotic symptoms in the British population. The British Journal of Psychiatry, 185(4), 298-305. 
Johnstone, E. C., Ebmeier, K. P., Miller, P., Owens, D. G., \& Lawrie, S. M. (2005). Predicting schizophrenia: findings from the Edinburgh high-risk study. The British Journal of Psychiatry, 186(1), 18-25.

Kaymaz, N., Drukker, M., Lieb, R., Wittchen, H. U., Werbeloff, N., Weiser, M., \& Van Os, J. (2012). Do subthreshold psychotic experiences predict clinical outcomes in unselected non-help-seeking population-based samples? A systematic review and meta-analysis, enriched with new results. Psychological Medicine, 42(11), 2239-2253.

Kelleher, I., Murtagh, A., Molloy, C., Roddy, S., Clarke, M. C., Harley, M., \& Cannon, M. (2011). Identification and characterization of prodromal risk syndromes in young adolescents in the community: a population-based clinical interview study. Schizophrenia Bulletin, 38(2), 239-246.

Kelleher, I., Wigman, J. T., Harley, M., O'Hanlon, E., Coughlan, H., Rawdon, C., \& Cannon, M. (2015). Psychotic experiences in the population: Association with functioning and mental distress. Schizophrenia Research, 165(1), 9-14.

Kendler, K. S., Gallagher, T. J., Abelson, J. M., \& Kessler, R. C. (1996). Lifetime prevalence, demographic risk factors, and diagnostic validity of nonaffective psychosis as assessed in a US community sample: The National Comorbidity Survey. Archives of General Psychiatry, 53(11), 1022-1031.

Kinoshita, Y., Shimodera, S., Nishida, A., Kinoshita, K., Watanabe, N., Oshima, N., \& Okazaki, Y. (2011). Psychotic-like experiences are associated with violent behavior in adolescents. Schizophrenia Research, 126(1), 245-251.

Lataster, T., van Os, J., Drukker, M., Henquet, C., Feron, F., Gunther, N., \& MyinGermeys, I. (2006). Childhood victimisation and developmental expression of 
non-clinical delusional ideation and hallucinatory experiences. Social Psychiatry and Psychiatric Epidemiology, 41(6), 423-428.

McGrath, J. J., Saha, S., Al-Hamzawi, A., Alonso, J., Bromet, E. J., Bruffaerts, R., \& Florescu, S. (2015). Psychotic experiences in the general population: A crossnational analysis based on 31261 respondents from 18 countries. JAMA Psychiatry, 72(7), 697-705.

Morrison, A. P. (2001). The interpretation of intrusions in psychosis: an integrative cognitive approach to hallucinations and delusions. Behavioural and Cognitive Psychotherapy, 29(3), 257-276.

Murphy, S., Murphy, J., \& Shevlin, M. (2015). Negative evaluations of self and others, and peer victimization as mediators of the relationship between childhood adversity and psychotic experiences in adolescence: the moderating role of loneliness. British Journal of Clinical Psychology, 54(3), 326-344.

Olfson, M., Lewis-Fernández, R., Weissman, M. M., Feder, A., Gameroff, M. J., Pilowsky, D., \& Fuentes, M. (2002). Psychotic symptoms in an urban general medicine practice. American Journal of Psychiatry, 159(8), 1412-1419.

Pearson, D., Smalley, M., Ainsworth, C., Cook, M., Boyle, J., \& Flury, S. (2008). Auditory hallucinations in adolescent and adult students: Implications for continuums and adult pathology following child abuse. The Journal of Nervous and Mental Disease, 196(8), 634-638.

Poulton, R., Caspi, A., Moffitt, T. E., Cannon, M., Murray, R., \& Harrington, H. (2000). Children's self-reported psychotic symptoms and adult schizophreniform disorder: a 15-year longitudinal study. Archives of General Psychiatry, 57(11), 1053-1058. 
Reininghaus, U., Priebe, S., \& Bentall, R. P. (2012). Testing the psychopathology of psychosis: Evidence for a general psychosis dimension. Schizophrenia Bulletin, 39(4), 884-895.

Remberk, B. (2017). Clinical significance of psychotic-like experiences in children and adolescents. Psychiatria Polska, 51(2), 271-282.

Rössler, W., Riecher-Rössler, A., Angst, J., Murray, R., Gamma, A., Eich, D., van Os, J. \& Gross, V.A., (2007). Psychotic experiences in the general population: a twenty-year prospective community study. Schizophrenia Research, 92(1-3), 114.

Shevlin, M., Boyda, D., Houston, J., \& Murphy, J. (2015). Measurement of the psychosis continuum: Modelling the frequency and distress of subclinical psychotic experiences. Psychosis, 7(2), 108-118.

Shevlin, M., McElroy, E., Bentall, R. P., Reininghaus, U., \& Murphy, J. (2016). The psychosis continuum: Testing a bifactor model of psychosis in a general population sample. Schizophrenia Bulletin, 43(1), 133-141.

Shevlin, M., Murphy, J., Dorahy, M. J., \& Adamson, G. (2007). The distribution of positive psychosis-like symptoms in the population: A latent class analysis of the National Comorbidity Survey. Schizophrenia Research, 89(1), 101-109.

Smeets, F., Lataster, T., Dominguez, M. D. G., Hommes, J., Lieb, R., Wittchen, H. U., \& van Os, J. (2010). Evidence that onset of psychosis in the population reflects early hallucinatory experiences that through environmental risks and affective dysregulation become complicated by delusions. Schizophrenia Bulletin, 38(3), 531-542. 
Stefanovics, E. A., Elkis, H., Zhening, L., Zhang, X. Y., \& Rosenheck, R. A. (2014). A cross-national factor analytic comparison of three models of PANSS symptoms in schizophrenia. Psychiatry Research, 219(2), 283-289.

van Os, J., Hanssen, M., Bijl, R. V., \& Vollebergh, W. (2001). Prevalence of psychotic disorder and community level of psychotic symptoms: An urban-rural comparison. Archives of General Psychiatry, 58(7), 663-668.

Varese, F., Smeets, F., Drukker, M., Lieverse, R., Lataster, T., Viechtbauer, W., ... \& Bentall, R. P. (2012). Childhood adversities increase the risk of psychosis: a meta-analysis of patient-control, prospective-and cross-sectional cohort studies. Schizophrenia Bulletin, 38(4), 661-671.

Waters, F., Allen, P., Aleman, A., Fernyhough, C., Woodward, T. S., Badcock, J. C., Larøi, F., \& Vercammen, A. (2012). Auditory hallucinations in schizophrenia and nonschizophrenia populations: a review and integrated model of cognitive mechanisms. Schizophrenia Bulletin, 38(4), 683-693.

Wigman, J. T., van Nierop, M., Vollebergh, W. A., Lieb, R., Beesdo-Baum, K., Wittchen, H. U., \& van Os, J. (2012). Evidence that psychotic symptoms are prevalent in disorders of anxiety and depression, impacting on illness onset, risk, and severity-Implications for diagnosis and ultra-high risk research. Schizophrenia Bulletin, 38(2), 247-257.

Yung, A. R., Nelson, B., Baker, K., Buckby, J. A., Baksheev, G., \& Cosgrave, E. M. (2009). Psychotic-like experiences in a community sample of adolescents: Implications for the continuum model of psychosis and prediction of schizophrenia. Australian \& New Zealand Journal of Psychiatry, 43(2), 118-12. Zammit, S., Hamshere, M., Dwyer, S., Georgiva, L., Timpson, N., Moskvina, V., Richards, A., Evans, D.M., Lewis, G., Jones, P. and Owen, M.J., (2013). A 
population-based study of genetic variation and psychotic experiences in adolescents.

Schizophrenia Bulletin, 40(6), 1254-1262.

The authors report no conflict of interest. 
Table 1. Summary of Psychotic-Like Experiences Studies Among Community, High-Risk and Clinical Samples.

\begin{tabular}{|c|c|c|c|c|c|}
\hline Group & Study & Sample & $\begin{array}{l}\text { Measurement } \\
\text { Instrument }\end{array}$ & $\begin{array}{l}\text { Reports of Undifferentiated } \\
\text { PLE Results }\end{array}$ & $\begin{array}{l}\text { Reports of Specific } \\
\text { PLE Prevalence/ Results }\end{array}$ \\
\hline \multicolumn{6}{|c|}{ Community } \\
\hline & $\begin{array}{l}\text { Dhossche et al. } \\
\text { (2002) }\end{array}$ & $\begin{array}{l}\mathrm{N}=914 . \\
\mathrm{N}=783 .\end{array}$ & $\begin{array}{l}\text { YSR, } \\
\text { CIDI, } \\
\text { AYSR. }\end{array}$ & $\begin{array}{l}\text { 6\%- one PLE. } \\
\text { 3\%- one PLE. }\end{array}$ & $\begin{array}{l}\text { 5\%- AH. } \\
\text { 2\%- VH. } \\
\text { 2\%- AH. } \\
\text { 2\%- VH. }\end{array}$ \\
\hline & $\begin{array}{l}\text { Dominguez et } \\
\text { al. (2011) }\end{array}$ & $\mathrm{N}=845$ & $\begin{array}{l}\text { M-CIDI } \\
\text { SCL-90-R }\end{array}$ & $\begin{array}{l}\text { T0-T2-21.8\% PLEs } \\
\text { T3- 12.7\% PLEs }\end{array}$ & \\
\hline & $\begin{array}{l}\text { Gale et al. } \\
\text { (2011) }\end{array}$ & $\mathrm{N}=7435$. & CIDI & 7.30\%- PLEs. & $\begin{array}{l}5.30 \%-\mathrm{VH} . \\
2.80 \%-\mathrm{AH} .\end{array}$ \\
\hline & $\begin{array}{l}\text { Hanssen et al } \\
(2005)\end{array}$ & $\mathrm{N}=4,042$ & NEMESIS & $2 \%$ - at least one PLE & \\
\hline & $\begin{array}{l}\text { Horwood et al. } \\
(2008)\end{array}$ & $\mathrm{N}=6455$ & $\begin{array}{l}\text { PLIKSi, } \\
\text { DISC-IV, } \\
\text { SCAN 2.0. }\end{array}$ & $\begin{array}{l}38.9 \% \text { - one or more PLE. } \\
18.2 \% \text { - two or more PLEs. } \\
9.3 \% \text { - three or more PLEs. }\end{array}$ & $\begin{array}{l}\text { 7.30\%- AH. } \\
4.00 \% \text { - VH. } \\
3.00 \% \text { - Being spied upon. } \\
1.10 \% \text { - Grandiose delusions. } \\
0.60 \% \text { - Thoughts read. } \\
0.30 \% \text { - Feelings of persecution. }\end{array}$ \\
\hline
\end{tabular}




\begin{tabular}{|c|c|c|c|c|}
\hline $\begin{array}{l}\text { McGrath et al. } \\
\text { (2015) }\end{array}$ & $\mathrm{N}=31,261$ & CIDI. & $\begin{array}{l}5.8 \% \text { - one PLE. } \\
5.2 \% \text { - HE. } \\
1.3 \% \text { - DE. }\end{array}$ & $\begin{array}{l}3.8 \%-\mathrm{VH} . \\
2.5 \%-\mathrm{AH} . \\
0.7 \%-\text { Being spied on. }\end{array}$ \\
\hline $\begin{array}{l}\text { Poulton et al. } \\
(2000)\end{array}$ & $\mathrm{N}=1037$ & $\begin{array}{l}\text { DISC-C, } \\
\text { DIS. }\end{array}$ & $\begin{array}{l}\text { Control; } \\
\text { Age } 11=86 \% \text { reported PLEs. } \\
\text { Age } 26=2 \% \text { reported PLEs. } \\
\text { Weak PLEs; } \\
\text { Age } 11=13 \% \\
\text { Age } 26=9.5 \% \\
\text { Strong PLEs; } \\
\text { Age } 11=1.6 \% \\
\text { Age } 26=25 \%\end{array}$ & \\
\hline $\begin{array}{l}\text { Shevlin et al. } \\
(2007)\end{array}$ & $\mathrm{N}=5893$ & CIDI & & $\begin{array}{l}12.9 \% \text { - being spied on. } \\
8.3 \% \text { - AH. } \\
8.4 \% \text { - VH. } \\
7.4 \% \text { - Thoughts being read. } \\
\text { 4.0\%- Thought broadcast. } \\
3.6 \% \text { - Paranoia. } \\
3.1 \% \text { - Feeling controlled. } \\
2.4 \% \text { - Grandiose type delusions. } \\
2.2 \% \text { - Thought insertion. }\end{array}$ \\
\hline $\begin{array}{l}\text { Rossler et al. } \\
(2006)\end{array}$ & $\mathrm{N}=372$ & $\begin{array}{l}\text { SCL90-R, } \\
\text { SPIKE }\end{array}$ & & $\begin{array}{l}\text { T1-T6: } \\
\text { 42.8\%-33.3- Being spied on. } \\
\text { 38.3\%-15.2\%- Thoughts read. } \\
\text { 18.5\%-0.10\%- Thought broadcast. } \\
3.20 \%-0.10 \% \text {-AH. }\end{array}$ \\
\hline
\end{tabular}




\begin{tabular}{|c|c|c|c|c|c|}
\hline & $\begin{array}{l}\text { Wiles et al } \\
(2006)\end{array}$ & $\mathrm{N}=8580$ & $\begin{array}{l}\text { CIS-R, PSQ, } \\
\text { SCAN. }\end{array}$ & $\begin{array}{l}\mathrm{T} 1=10.9 \% \text { reported PLEs. } \\
\mathrm{T} 2=3.3 \% \text { reported PLEs. }\end{array}$ & \\
\hline & $\begin{array}{l}\text { Zammit et al } \\
(2013)\end{array}$ & $\mathrm{N}=4,724$ & PLSI ,SCAN & $\begin{array}{l}\text { Between ages } 12-18 ; \\
9.2 \% \text { suspected PLEs } \\
\text { 4.9\% definite PLEs } \\
\text { 62.8\% - one PLE } \\
21.0 \% \text { - two PLEs } \\
\text { 8.8\% - three PLEs } \\
7.4 \% \text {-four PLES }\end{array}$ & $\begin{array}{l}5.4 \%-\mathrm{AH} \\
4.2 \%-\mathrm{VH} \\
1.7 \%-\text { Being spied on }\end{array}$ \\
\hline \multicolumn{6}{|l|}{ High Risk } \\
\hline & $\begin{array}{l}\text { Kinoshita et al. } \\
\text { (2011) }\end{array}$ & $\mathrm{N}=19,436$ & DIS-C & $14.40 \%$-PLEs. & $\begin{array}{l}9.60 \%-\text { AH. } \\
6.40 \%-\text { Being spied on. } \\
1.90 \%-\text { Thoughts read. }\end{array}$ \\
\hline & $\begin{array}{l}\text { Lataster et al. } \\
(2006)\end{array}$ & $\mathrm{N}=1290$ & YHCD. & & $\begin{array}{l}\text { 12.7\%- Being spied on. } \\
7.00 \% \text { - AH. } \\
4.70 \% \text { - Thought insertion. }\end{array}$ \\
\hline
\end{tabular}




\begin{tabular}{|c|c|c|c|c|}
\hline $\begin{array}{l}\text { Olfson et al. } \\
(2002)\end{array}$ & $\mathrm{N}=1005$ & $\begin{array}{l}\text { Mini } \\
\text { International } \\
\text { Neuro- } \\
\text { psychiatric } \\
\text { Interview } \\
(30) \text {. }\end{array}$ & 20.9\% PLEs. & $\begin{array}{l}\text { 61.0\%- AH. } \\
51.0 \% \text { - Being spied on. } \\
49.5 \% \text { - VH. } \\
32.9 \% \text { - Feelings of persecution. } \\
31.9 \% \text { - Thought insertion. } \\
31.0 \% \text { - Thought broadcasting. } \\
18.7 \% \text { - Feeling controlled by an external } \\
\text { force. }\end{array}$ \\
\hline $\begin{array}{l}\text { Pearson et al. } \\
(2008)\end{array}$ & $\mathrm{N}=500$ & $\begin{array}{l}\text { Hallucination } \\
\text { Questionnair } \\
\text { e. }\end{array}$ & $\begin{array}{l}\text { Adolescents; } 36.7 \% \text { one HE. } \\
39.2 \% \text { two or more HEs. } \\
\text { Adults; } 35.2 \% \text { one HE. } \\
29 \% \text { two or more HEs. } \\
\text { Overall study; } 36 \% 1 \mathrm{HE} \text {. } \\
34.2 \% \text { two or more HEs }\end{array}$ & \\
\hline $\begin{array}{l}\text { Smeets et al. } \\
(2010)\end{array}$ & $\mathrm{N}=2524$ & $\begin{array}{l}\text { SCL-90R, M- } \\
\text { CIDI. }\end{array}$ & $\begin{array}{l}\text { PLEs; } 2-3.1 \% \\
\text { HEs; } 3.1-4 / 6 \% \\
\text { DEs; } 11-21.0 \%\end{array}$ & $\begin{array}{l}\text { T2-T3; } \\
\text { 34.4-33.2\%- Spied on } \\
\text { 28.2-38.5\%- AH } \\
\text { 25.3-22.0\%- Persecution } \\
\text { 23.1-15.4\%- VH } \\
\text { 19.1-13.7\%- Paranoia } \\
\text { 15.3-9.80\%- Thoughts read } \\
\text { 4.70\%-4.40\%- Thought Broadcast } \\
\text { 3.35-2.90\%- Control } \\
\text { 2.20\%-0.50\%- Thought Insertion } \\
0.70 \%-0.50 \% \text { - Thought Withdrawal }\end{array}$ \\
\hline
\end{tabular}




\begin{tabular}{|c|c|c|c|c|c|}
\hline \multicolumn{6}{|l|}{ Clinical } \\
\hline & $\begin{array}{l}\text { Cougnard et al. } \\
\text { (2007) }\end{array}$ & $\begin{array}{l}\text { NEMESIS } \\
\mathrm{N}=4786 \\
\text { EDSP } \\
\mathrm{N}=2452\end{array}$ & $\begin{array}{l}\text { CIDI, } \\
\text { SCL-90-R, } \\
\text { M-CIDI. }\end{array}$ & $\begin{array}{l}\text { NEMESIS Sample; } \\
\text { T1=16.1\%- PLEs. } \\
\text { EDSP Sample; } \\
\text { T1=9.3\%- PLEs. }\end{array}$ & \\
\hline & $\begin{array}{l}\text { Kelleher et al. } \\
(2015)\end{array}$ & $\mathrm{N}=108$ & $\begin{array}{l}\text { K-SADS, } \\
\text { CGAS. }\end{array}$ & 46\%- PLEs. & $\begin{array}{l}63 \% \text { - Being spied on. } \\
50 \% \text { - AH. } \\
29 \% \text { - VH. } \\
21 \% \text { - Thought withdrawal. }\end{array}$ \\
\hline
\end{tabular}

Note: The instruments which directly inform about the prevalence rates of PLEs are shown; T1: First measurement; T2: Second measurement; HE: Hallucinatory Experiences; AH: Auditory Hallucination; VH: Visual Hallucination; HQ: Hallucination Questionnaire; YSR: Youth Self Report; AYSR: Young Adult Self Report; M-CIDI: Munich-Composite International Diagnostic Interview; DISC-IV: Diagnostic Interview Schedule for Children; SCL- 90-R: Symptom Checklist-90-Revised; CIDI: Composite International Diagnostic Interview; SCAN; Schedules for Clinical Assessment in Neuropsychiatry: CGAS; The Children's Global Assessment Scale: K-SADS; The Kiddie Schedule for Affective Disorders and Schizophrenia: YHCD; Youth Health Care Division from the Municipal Health Centre Maastricht: PLIKSi; Psychosis-Like Symptom Interview: SCAN; Schedule for Clinical Assessment in Neuropsychiatry: PLSI; Psychosis-Like Symptom Interview. 
Table 2. Frequencies and Percentage Endorsement Rates of PLEs Across Three Samples.

\begin{tabular}{|c|c|c|c|c|c|c|c|c|}
\hline \multirow[b]{2}{*}{ Items } & \multirow[b]{2}{*}{ Group } & \multirow[b]{2}{*}{$\begin{array}{c}\text { Any PLE } \\
\text { Endorsement }\end{array}$} & \multicolumn{4}{|c|}{ How often does this happen? } & \multirow[b]{2}{*}{ Value (df) } & \multirow[b]{2}{*}{ Sig. } \\
\hline & & & Never & Sometimes & Often & $\begin{array}{l}\text { Nearly } \\
\text { Always }\end{array}$ & & \\
\hline \multirow{5}{*}{$\begin{array}{l}\text { Some people believe that their } \\
\text { thoughts can be read by another } \\
\text { person. Have other people ever } \\
\text { read your mind? }\end{array}$} & Adolescent Community & $38.3 \%$ & $484(61.7 \%)$ & $200(25.5 \%)$ & $71(9.10 \%)$ & $29(3.70 \%)$ & & \\
\hline & Sexual-Trauma & $39.6 \%$ & $162(60.4 \%)$ & $79(29.5 \%)$ & $23(8.60 \%)$ & $4(1.50 \%)$ & & \\
\hline & Clinical & $48.0 \%$ & $26(52.0 \%)$ & $10(20.0 \%)$ & $7(14.0 \%)$ & $7(14.0 \%)$ & & \\
\hline & Chi-square & & & & & & $22.3(6)$ & .001 \\
\hline & Cramer's V & & & & & & .101 & .001 \\
\hline \multirow{5}{*}{$\begin{array}{l}\text { Have you ever had messages sent } \\
\text { just to you through the TV or } \\
\text { radio? }\end{array}$} & Adolescent Community & $21.7 \%$ & $613(78.3 \%)$ & $128(16.3 \%)$ & $28(3.60 \%)$ & $14(1.80 \%)$ & & \\
\hline & Sexual-Trauma & $13.8 \%$ & $231(86.2 \%)$ & $32(11.9 \%)$ & $4(1.50 \%)$ & $1(0.40 \%)$ & & \\
\hline & Clinical & $56.0 \%$ & $22(44.0 \%)$ & $14(28.0 \%)$ & $8(16.0 \%)$ & $6(12.0 \%)$ & & \\
\hline & Chi-Square & & & & & & $71.5(6)$ & .000 \\
\hline & Cramer's V & & & & & & .180 & .000 \\
\hline \multirow{5}{*}{$\begin{array}{l}\text { Have you ever thought that } \\
\text { people are following or spying on } \\
\text { you? }\end{array}$} & Adolescent Community & $40.5 \%$ & $466(59.5 \%)$ & $231(29.5 \%)$ & $53(6.80 \%)$ & $33(4.20 \%)$ & & \\
\hline & Sexual-Trauma & $59.7 \%$ & $108(40.3 \%)$ & $114(42.5 \%)$ & $38(14.20 \%)$ & $8(3.00 \%)$ & & \\
\hline & Clinical & $62.0 \%$ & $19(38.0 \%)$ & $14(28.0 \%)$ & $8(16.0 \%)$ & $9(18.0 \%)$ & & \\
\hline & Chi-Square & & & & & & $63.5(6)$ & .000 \\
\hline & Cramer's V & & & & & & .170 & .000 \\
\hline \multirow{6}{*}{$\begin{array}{l}\text { Have you ever heard voices or } \\
\text { sounds that no one else can hear? }\end{array}$} & Adolescent Community & $29.9 \%$ & $548(70.1 \%)$ & $156(19.9 \%)$ & $54(6.90 \%)$ & $24(3.10 \%)$ & & \\
\hline & Sexual-Trauma & $54.8 \%$ & $121(45.1 \%)$ & $84(31.3 \%)$ & $41(15.3 \%)$ & $22(8.20 \%)$ & & \\
\hline & Clinical & $78.0 \%$ & $11(22.0 \%)$ & $14(28.0 \%)$ & $13(26.0 \%)$ & $12(24.0 \%)$ & & \\
\hline & Chi-Square & & & & & & $118.4(6)$ & .000 \\
\hline & Cramer's V & & & & & & .232 & .000 \\
\hline & Adolescent Community & $14.0 \%$ & $668(86.0 \%)$ & $62(8.00 \%)$ & $24(3.10 \%)$ & $23(3.00 \%)$ & & \\
\hline
\end{tabular}




\begin{tabular}{|c|c|c|c|c|c|c|c|c|}
\hline \multirow{4}{*}{$\begin{array}{l}\text { Have you ever felt you were } \\
\text { under the control of some special } \\
\text { power? }\end{array}$} & Sexual-Trauma & $18.3 \%$ & $219(81.7 \%)$ & $32(11.9 \%)$ & $11(4.10 \%)$ & $6(2.20 \%)$ & & \\
\hline & Clinical & $36.0 \%$ & $32(64.0 \%)$ & $9(18.0 \%)$ & $6(12.0 \%)$ & $3(6.00 \%)$ & & \\
\hline & Chi-Square & & & & & & $22.5(6)$ & .001 \\
\hline & Cramer's V & & & & & & .101 & .001 \\
\hline \multirow{5}{*}{$\begin{array}{l}\text { Have you ever seen things that } \\
\text { other people could not see? }\end{array}$} & Adolescent Community & $23.4 \%$ & $596(76.6 \%)$ & $125(16.1 \%)$ & $31(4.00 \%)$ & $26(3.30 \%)$ & & \\
\hline & Sexual-Trauma & $45.4 \%$ & $146(54.5 \%)$ & $95(35.4 \%)$ & $21(7.80 \%)$ & $6(2.20 \%)$ & & \\
\hline & Clinical & $54.0 \%$ & $23(46.0 \%)$ & $15(30.0 \%)$ & $8(16.0 \%)$ & $4(8.00 \%)$ & & \\
\hline & Chi-Square & & & & & & $75.23(6)$ & .000 \\
\hline & Cramer's V & & & & & & .185 & .000 \\
\hline \multirow{5}{*}{$\begin{array}{l}\text { Have you ever felt like you had } \\
\text { extraspecial powers? }\end{array}$} & Adolescent Community & $14.5 \%$ & $668(85.5 \%)$ & $56(7.20 \%)$ & $25(3.20 \%)$ & $32(4.10 \%)$ & & \\
\hline & Sexual-Trauma & $22.5 \%$ & $208(77.6 \%)$ & $46(17.2 \%)$ & $9(3.40 \%)$ & $5(1.90 \%)$ & & \\
\hline & Clinical & $38.0 \%$ & $31(62.0 \%)$ & $9(18.0 \%)$ & $5(10.0 \%)$ & $5(10.0 \%)$ & & \\
\hline & Chi-Square & & & & & & $41.1(6)$ & .000 \\
\hline & Cramer's V & & & & & & .137 & .000 \\
\hline
\end{tabular}


Table 3. Frequencies and Percentage of PLEs Related Distress.

\begin{tabular}{|c|c|c|c|c|c|c|c|c|c|}
\hline \multirow[b]{2}{*}{ Items } & \multirow[b]{2}{*}{ Group } & \multirow[b]{2}{*}{$\begin{array}{c}\text { Total } \\
\mathbf{N}\end{array}$} & \multirow[b]{2}{*}{$\begin{array}{l}\text { Any PLE } \\
\text { Distress }\end{array}$} & \multicolumn{4}{|c|}{ How distressed are you by this? } & \multirow[b]{2}{*}{ Value (df) } & \multirow[b]{2}{*}{ Sig } \\
\hline & & & & $\begin{array}{c}\text { Not } \\
\text { Distressed } \\
\end{array}$ & $\begin{array}{c}\text { A bit } \\
\text { Distressed }\end{array}$ & $\begin{array}{c}\text { Quite } \\
\text { Distressed }\end{array}$ & $\begin{array}{c}\text { Very } \\
\text { Distressed } \\
\end{array}$ & & \\
\hline \multirow{3}{*}{$\begin{array}{l}\text { Some people believe that their } \\
\text { thoughts can be read by another } \\
\text { person. Have other people ever } \\
\text { read your mind? }\end{array}$} & Adolescent Community & 291 & $32.7 \%$ & $196(67.4 \%)$ & $68(23.4 \%)$ & $14(4.80 \%)$ & $13(4.50 \%)$ & & \\
\hline & Sexual-Trauma & 106 & $75.5 \%$ & $26(24.5 \%)$ & $34(32.1 \%)$ & $35(33.0 \%)$ & $11(10.4 \%)$ & & \\
\hline & Clinical & 24 & $91.7 \%$ & $2(8.30 \%)$ & $6(25.0 \%)$ & $7(29.2 \%)$ & $9(37.5 \%)$ & & \\
\hline \multirow{5}{*}{$\begin{array}{l}\text { Have you ever had messages sent } \\
\text { just to you through the TV or } \\
\text { radio? }\end{array}$} & Adolescent Community & 166 & $36.9 \%$ & $106(63.9 \%)$ & $40(24.1 \%)$ & $11(6.6 \%)$ & $9(5.40 \%)$ & & \\
\hline & Sexual-Trauma & 37 & $64.8 \%$ & $13(35.1 \%)$ & $13(35.1 \%)$ & $4(10.8 \%)$ & $7(18.9 \%)$ & & \\
\hline & Clinical & 28 & $100 \%$ & 0 & $6(21.4 \%)$ & $6(21.4 \%)$ & $16(57.1 \%)$ & & \\
\hline & Chi-square & & & & & & & $75.9(6)$ & .000 \\
\hline & Cramer's V & & & & & & & .405 & .000 \\
\hline \multirow{2}{*}{$\begin{array}{l}\text { Have you ever thought that } \\
\text { people are following or spying on } \\
\text { you? }\end{array}$} & Chi-square & & & & & & & $75.1(6)$ & .000 \\
\hline & Cramer's V & & & & & & & .275 & .000 \\
\hline \multirow{4}{*}{$\begin{array}{l}\text { Have you ever heard voices or } \\
\text { sounds that no one else can hear? }\end{array}$} & Adolescent Community & 230 & $67.3 \%$ & $75(32.6 \%)$ & $84(36.5 \%)$ & $44(19.1 \%)$ & $27(11.7 \%)$ & & \\
\hline & Sexual-Trauma & 147 & $80.9 \%$ & $28(19.0 \%)$ & $55(37.4 \%)$ & $40(27.2 \%)$ & $24(16.3 \%)$ & & \\
\hline & Clinical & 38 & $94.7 \%$ & $2(5.30 \%)$ & $6(15.8 \%)$ & $7(18.4 \%)$ & $23(60.5 \%)$ & & \\
\hline & Chi-square & & & & & & & $64.3(6)$ & .000 \\
\hline
\end{tabular}




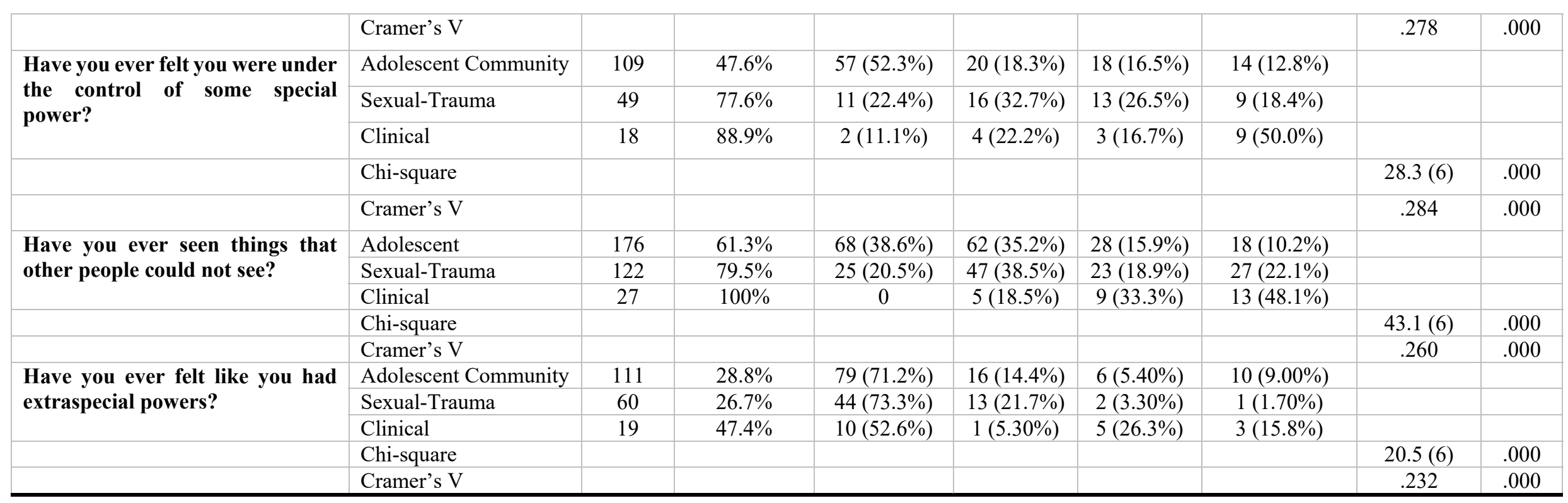

